\title{
Contents, Vol. 211, No. 3, 1997
}

\section{Contents Vol. 211, No. 3, 1997}

125 Preface

Lütjen-Drecoll, E. (Erlangen)

126 Cellular Pharmacology and Molecular Biology of the Trabecular MeshworkInducible Glucocorticoid Response Gene Product

Polansky, J.R.; Fauss, D.J.; Chen, P.; Chen, H. (San Francisco, Calif.); Lütjen-Drecoll, E.

(Erlangen); Johnson, D. (Rochester, Minn.); Kurtz, R.M. (Ann Arbor, Mich.); Ma, Z.-D.; Bloom, E.; Nguyen, T.D. (San Francisco, Calif.)

140 Ultrastructural Changes in the Trabecular Meshwork of Juvenile Glaucoma

Furuyoshi, N.; Furuyoshi, M. (Kumamoto/Erlangen); Futa, R. (Kumamoto); Gottanka, J.; LütjenDrecoll, E. (Erlangen)

147 Trabecular Meshwork Phagocytosis in Glaucomatous Eyes

Matsumoto, Y.; Johnson, D.H. (Rochester, Minn.)

153 Effect of Diuretics, Channel Modulators and Signal Interceptors on Contractility of the Trabecular Meshwork

Wiederholt, M.; Dörschner, N.; Groth, J. (Berlin)

161 Choroidal Ganglion Cell Plexus and Retinal Vasculature in Monkeys with Laser-Induced Glaucoma

May, C.A. (Erlangen); Hayreh, S.S. (Iowa City, Iowa); Furuyoshi, N. (Erlangen); Ossoinig, K. (Iowa City, Iowa); Kaufman, P.L. (Madison, Wise); Lütjen-Drecoll, E. (Erlangen)

172 Retinal Capillary Hemodynamics and VEP/Pressure Tolerance: Evidence of Retinal

Microcirculator $\gamma$ Compromise in Treated Glaucomatous Eyes

Sponsel, W.E.; Zetlan, S.R.; Stodtmeister, R.; Kaufman, P.L. (Madison, Wise.)

178 Ocular Blood Flow in Experimental Glaucoma: A Study in Cynomolgus Monkeys

Aim, A. (Uppsala); Lambrou, G.N. (Strasbourg); Mäepea, O.; Nilsson, S.F.E. (Uppsala);

Percicot, C. (Basel)

183 The Three-Dimensional Structure of the Connective Tissue in the Lamina Cribrosa of the Human Optic Nerve Head

Birch, M.; Brotchie, D.; Roberts, N.; Grierson, I. (Liverpool)

192 Peroxide-Induced Damage in Lenses of Transgenic Mice with Deficient and Elevated Levels of Glutathione Peroxidase

Reddy, V.N.; Lin, L.-R. (Rochester, Mich.); Ho, Y.-S.; Magnenat, J.-L. (Detroit, Mich.); Ibaraki, N,; Giblin, F.J.; Dang, L. (Rochester, Mich.)

201 Nitrergic Nerve Cells in the Primate Ciliary Muscle Are Only Present in Species with a

Fovea centralis

Tamm, E.R.; Lütjen-Drecoll, E. (Erlangen)

KAR.GEK (C) 1997 S.KargerAG, Basel 123

E-Mail karger@karger.ch The list of contents is available at:

F. Fax+41613061234 http://www.karger.ch/journals/oph/ophcont.htm 
http://www.karger.ch 